\title{
Stability Enhancement of a Plastic Additive (Dimethyl Phthalate, DMP) with Environment-Friendly Based on 3D-QSAR Model
}

\author{
Haigang Zhang*, Chengji Zhao, Hui Na \\ Alan G. MacDiarmid Institute, Jilin University, Changchun 130012, China
}

Received: 31 July 2020

Accepted: 26 November 2020

\begin{abstract}
Phthalic acid esters (PAEs) are the main additive components of plastics. They can diffuse and migrate during the use and processing of plastics, and they also affect the properties of plastics and pollute the environment. In this study, the comparative molecular similarity index (CoMSIA) was used to construct a three-dimensional quantitative structure-activity relationship (3D-QSAR) model with the valuation index of the volatility of PAEs. Dimethyl phthalate (DMP), an environmental priority pollutant, was selected as a target molecule. The substitution sites and substituent groups in PAE volatilization were determined according to three-dimensional potentiometric map information of the CoMSIA model. Eleven electronegative groups and hydrophilic groups were selected to modify the target molecule through single and double displacement reactions. A total of 55 PAE derivatives were designed, and 19 of those derivatives had an increase in the volatility rating of more than $10 \%$. Based on these derivatives, the environmental friendliness model was used to evaluate the biotoxicity, persistence, and bio-enrichment of PAE derivatives. Seven PAE derivatives with low biotoxicity, persistence, and bio-enrichment were selected. Compared with the plasticizer before modification, DMP derivatives have higher stability and are less likely to volatilize into the environment due to migration and diffusion in plastic products.
\end{abstract}

Keywords: phthalic acid esters, volatility, three-dimensional quantitative structure-activity relationship, environmental friendliness, stability

\section{Introduction}

Plastics are generally produced by the polymerization of monomers derived from oil, gas, or coal, and they

*e-mail: zhanghg18@mails.jlu.edu.cn are organic polymers with a high molecular weight [1], for example, polyvinyl chloride (PVC), polystyrene (PS), polyethylene (PE), polypropylene (PP), and polyester (PET) [2]. As a kind of high-molecular-weight polymer, plastics have a strong intermolecular force, high melting point, and small processing-temperature range. Therefore, a plasticizer is needed to reduce the 
intermolecular force and increase the mobility of the molecular chain in the process of plastic production and processing [3]. Phthalic acid esters (PAEs) are the main additive component of plasticizers in plastic products, accounting for about $85 \%$ of the global plasticizer market [4-5], and are widely used in all kinds of plasticizers. PAEs are used as plasticizers in the polymer industry to improve suppleness, machinability, and general handing properties, and $80 \%$ of plasticizers for this purpose are PAEs [6].

PAEs are semi-volatile organic compounds (SVOCs), which volatilize from plastic products and migrate to the external environment over the time during the processing and use of plastics [7]. With the rapid development of the plastic industry and the widespread applications of plastic products, PAEs will enter the environment in large quantities and exist in the atmosphere, soil, oceans, rivers, and lakes, making them one of the most ubiquitous pollutants in the world. PAEs have the characteristics of biotoxicity, bioaccumulation, and refractory degradation, and will remain at a certain residual level in the environment [8]. Because there is no acute toxicity of PAEs, people may inadvertently come in contact with PAEs or be exposed to PAEs for a long time [9], which will gradually harm their health [10]. PAEs also impact the estrogen activity [11], which can lead to sexual prematurity in women [12] and harm the human liver tissue [13], reproductive development, and central nervous system [14]. Since PAEs have reached a level that can be detected in major industrialized countries around the world, the U.S. Environmental Protection Agency (EPA) has designated six PAEs - di- $n$-octyl phthalate (DNOP), dibutyl phthalate (DBP), dimethyl phthalate (DMP), diethyl phthalate (DEP), butyl benzyl phthalate (BBP), and di-(2-ethylhexyl) phthalate (DEHP) - as environmental priority pollutants. Of these, DMP, DBP, and DNOP are listed as environmental priority pollutants in China [15].

The plasticizer and plastic molecules experience the van der Waals force, and a hydrogen bond exists between the two. Further, plasticizers are prone to migration and diffusion. There are four main modes of plasticizer migration and diffusion [16]: (1) The plasticizers volatilize from the surface of plastic products into the atmosphere. (2) The plasticizers are extracted out via a liquid phase in contact with the plastic. (3) The plasticizers migrate and diffuse into solid or semisolid materials in contact with plastic products. (4) The plasticizers ooze from the plastic under pressure. The volatilization and diffusion of plasticizers can be considered as small molecules migrating between the polymer chain segments. Common methods for inhibiting the plasticizer diffusion and migration are reducing the movement of the polymer chain segment, reducing the space between molecular chains of the polymer and mixing with other materials [3]. The modification of the plasticizer to reduce the volatility of PAEs in order to inhibit its diffusion and migration is also worth studying. Some scholars have explored the volatility of PAEs in the environment [17-18]. As a medium-polarity substance, PAEs are soluble in organic solvents but insoluble in water [19]. Therefore, when the water environment changes, PAEs can easily migrate from the water to the atmosphere. The migration trend of PAEs from water to the atmosphere can be described by the chemical equilibrium coefficient between water and the atmosphere (i.e., the ratio of the atmospheric pressure to the molar concentration of the solution), namely, Henry's constant $(\mathrm{H})$. If $\mathrm{H}$ of a substance is lower than $10^{-7}$, no volatilization occurs in the aqueous solution. For both low-molecular-weight and highmolecular-weight PAE solutions, the $\mathrm{H}$ value ranges from $(1.2-8.8) \times 10^{-5}$ to $(1.7-5.5) \times 10^{-5}$, respectively, which are all higher than $10^{-7}$. Moreover, as the $\mathrm{H}$ value of PAEs increases, the probability of volatilization from water to the atmosphere also increases [20]. The vapor pressure is an important physical, and chemical parameter used to characterize the migration trend of pure compounds into the air. It can be used as an evaluation standard for the mobility of substances: the greater the vapor pressure is, the higher mobility is [21].

Molecular modification is a mature science and technology method for improving the properties of substances. In recent years, some scholars have explored and studied the optimization of various properties of PAEs utilizing molecular modification. Qiu et al. [22] constructed a pharmacophore model of estrogen activity, and molecular modification and high fluorescence intensity was used as a screening method to obtain 12 PAE derivatives with low estrogen activity and high fluorescence intensity. Han et al. [23] constructed a pharmacophore models of PAEs' hormone combined activity and performed a common hydrogen bond donor substitution reactions on PAEs molecules. 11 PAE derivative molecules with significantly reduced combined activity and single activity were screened, and it confirmed the feasibility of the modified PAEs modification scheme with reduced combined activities of hormones. Li et al. [24] established a 3D-QSAR model for the toxicity and estrogen combined activities of PAEs. 4 kinds of PAE derivatives with practicability and environmental friendliness were designed, and the molecular docking mechanism showed that the reduced hydrophobicity may affect the binding effect in estrogen-related proteins. Zhang et al. [25] modified the phthalate acid esters with multispectral activity pharmacophore model, and provided theoretical support for the development of technology to enhance spectrum detection for phthalate acid esters. Qiu et al. [26] constructed a 3D-QSAR pharmacophore models of UV absorption intensities for PAEs and designed 14 PAE derivatives. The effects of solvation and derivatization on the UV absorption intensities were analyzed. Zhang et al. [27] used the ideal point method, a flammability, 
biotoxicity, and enrichment multi-effect 3D-QSAR model for PAEs was developed, and it has been successfully applied to the modification of PAEs with high flame retardancy, low biological toxicity and low enrichment. Zhang et al. [28] constructed a 3D-QSAR pharmacophore model with dual biodegradation effects and designed PAE derivative molecules with high biodegradability in marine and freshwater environments based on the model. Zhang et al. [29] constructed a 3D-QSAR model of the comprehensive biodegradability of PAEs and designed for PAE derivatives suitable for degradation by plasticizer-degrading bacteria. Majority of studies in the existing literature focused on PAEs' environmental friendliness related factors such as toxicity and bio-enrichment, as well as dedicated to enhancing the various functions of PAEs. There is almost no research on the volatility of PAEs, especially on the application of PAEs volatility parameters for molecular modification. Considering that the volatility of PAEs is one of the most important factors affecting its performance as a plasticizer, this paper focuses on the research in this field.

In this paper, a three-dimensional quantitative structure-activity relationship (3D-QSAR) model was constructed based on PAE volatility evaluation index. DMP was used as the target molecule for modification. Through the comparison and analysis of the three-dimensional potentiometric map of the CoMSIA model of the target molecule, the modification sites of the target molecule were determined, suitable groups were selected for substitution reaction, and PAE derivative molecules with lower volatility than the target molecule were designed. The environmental friendliness (toxicity, persistence, and bio-enrichment) of PAE derivatives was evaluated by using the comprehensive environmental friendliness model, and for the first time, the reasonability of designed PAE derivative molecules are analyzed and verified using "element and chemical-bond contributions analysis". The aim is to design a low volatile and environmentally friendly plasticizer and use its stability enhancement to improve the stability of plastics.

\section{Materials and Methods}

\section{Data Sources}

In this study, the volatility of PAEs is used as the index to evaluate the stability of PAEs. The volatility is characterized by the vapor pressure (VP) of PAEs. $\mathrm{VP}$ values of $17 \mathrm{PAE}$ molecules were selected as the data source to construct the $3 \mathrm{D}-\mathrm{QSAR}$ model of PAE molecules. The VP data for BBP, DBP, DEP, DHP, and DMP are quoted from Wei's research [30]. The VP data for DAP, DIBP, DIHP, DIHXP, DIPP, DIPRP, DMEP, DNOP, DPP, DPRP, DTDP, and DUP were predicted by using the EPI Suite software.
Method for Constructing PAE Molecular Volatility (VP) CoMSIA Model

In this study, the 3D-QSAR module in the Sybyl-x2.0 software of Tripos Company was used for analysis, and the PAE molecular volatility was selected as the parameter to construct the CoMSIA model. By applying the Minimize module in Sybyl-x2.0, the structure of painted PAE molecules was optimized, the Powell conjugate gradient method was used, and the Tripos molecular force field was selected. The molecular charge was the Gasteiger-Hückel charge, and the energy convergence standard was set as $0.005 \mathrm{kcal} \bullet \mathrm{mol}^{-1}$. The number of iterations was set at 10000 , and other parameters are set as default values. The most stable conformer of PAEs (the highest VP value) is usually the most active molecule, and it also acts as a template molecule. In this study, DMP is used as a template molecule, because DMP has the highest activity among DMP, DNOP, and DBP. Other compounds perform substituent transformation and optimization of the structure of this template molecule to obtain a stable conformation, thus enabling the building of a molecular library. The database alignment module was used to perform the skeleton superposition of the compound.

First, 15 known VP values of 17 PAEs were randomly selected. At the ratio of 3:1, 12 PAEs were used as the training sets, and 4 PAEs were used as test sets. The partial least square regression (PLS) was used for the analysis. The compounds in the training set were crossvalidated by using the leave-one-out method module, so as to obtain the cross-validation coefficient $\mathrm{q}^{2}$ and the optimal number of principal components $\mathrm{n}$. Then, the regression analysis was conducted by no-validation regression to obtain the non-cross validation coefficient $\mathrm{R}^{2}$, values standard deviation $\mathrm{SEE}$, test value $\mathrm{F}$, and the contribution of the force field (steric, hydrophobic, and electrostatic field). Finally, the scrambling stability test was used to evaluate the robustness of the model (evaluation parameters were $\mathrm{Q}^{2}, \mathrm{cSDEP}$, and $\mathrm{dQ}^{2} / \mathrm{dr}^{2} \mathrm{yy}$ ), and in combination with cross-validation, to further test the external prediction ability of the model (evaluation parameters were SEP and $\mathrm{r}_{\text {pred }}^{2}$ ). The substituent sites and the substituent groups were determined by analyzing the three-dimensional equipotential map information of the model.

\section{Methods for Evaluating Environmental Friendliness and Functional Properties of PAE Derivatives}

The environmental friendliness of PAEs before and after modification can be characterized on the basis of three aspects: biotoxicity, persistence, and bio-enrichment. If the modified PAE derivative molecules have a lower biotoxicity, persistence, and bio-enrichment than the unmodified PAE derivative 
molecules, the modified PAE molecules can be considered to be environmentally friendly. In this study, PAE molecular biotoxicity, persistence, and bioenrichment models constructed by Qiu et al. [22] were used to predict their environmental harmfulness before and after modification. The biotoxicity was characterized on the basis of the lethal concentration $50 \%\left(\mathrm{LC}_{50}\right)$ of PAEs [31]. The bio-enrichment was characterized on the basis of bioconcentration factors $(\log B C F)$ of PAEs [32]. The persistence was characterized on the basis of the half-life $\left(\log t_{1 / 2}\right)$ of PAEs [33].

The energy gap, total energy, and frequency were used to evaluate the functional characteristics of PAEs before and after molecular modification [34]. The energy gap value is an important parameter that reflects the conductivity of a material, and it is the minimum energy required for electron excitation. Moreover, the larger energy gap value is, the weaker conductivity will be [35]. The total energy value represents the stability of the molecule in the environment. The frequency is used to determine whether the molecule is stable in the environment. In this study, using the Gaussian 09 software and based on the density functional theory (B3LYP), the $6-31 \mathrm{G}^{*}$ base group was used to calculate the energy gap, total energy, and frequency of PAEs before and after modification.

\section{Results and Discussion}

\section{Construction of a 3D-QSAR Model of PAE Molecules}

The VP value of PAE molecules was predicted by Wei [19] and by using the EPI suite, and the specific values are listed in Table 1.

Table 1 shows that the DMP, which is a priority pollutant, has the highest vapor pressure in the PAE molecular environment, and it was selected as the template molecule. In order to construct the PAE molecular volatility CoMSIA model, 15 PAE molecules were randomly selected for common skeleton superposition. The CoMSIA model parameters are shown in Table 2. As Table 2 shows, $\mathrm{n}$ was 8 , and $\mathrm{q}^{2}$ was $0.785(>0.5)$, indicating clearly that the model had a reliable predictive ability [36-37]. Further, SEE was $0.01(<0.95)$, $\mathrm{F}$ was 186.087 , and $\mathrm{R}^{2}$ was $0.998(>0.9)$, meaning that the model had the good fitting ability [38]. In addition, $\mathrm{Q}^{2}$ was 0.396 , cSDEP was 0.169 , and $\mathrm{dq}^{2} / \mathrm{dr}^{2}$ yy was 2.912 , showing that the model had good stability [39]. The test sets perform external validation, and SEP and $\mathrm{r}^{2}$ pred were 0.071 and $0.532 \quad(>0.5)$, respectively, indicating that the model had a good ability for external prediction [40]. In the CoMSIA model, the contributions of the electrostatic field, hydrophobic field, steric field, hydrogen bond acceptor field, and hydrogen

Table 1. The vapor pressure values of PAE molecules.

\begin{tabular}{|c|c|c|c|c|}
\hline No. & \multicolumn{2}{|c|}{ PAEs } & $\mathrm{VP}(\mathrm{Pa})$ & Formula \\
\hline 1 & Training set molecule & ${ }^{\mathrm{a} B B P}$ & 0.011 & $\mathrm{C}_{19} \mathrm{H}_{20} \mathrm{O}_{4}$ \\
\hline 2 & Training set molecule & ${ }^{\mathrm{a} D B P}$ & 0.097 & $\mathrm{C}_{16} \mathrm{H}_{22} \mathrm{O}_{4}$ \\
\hline 3 & Training set molecule & ${ }^{\mathrm{a} D E P}$ & 0.220 & $\mathrm{C}_{12} \mathrm{H}_{14} \mathrm{O}_{4}$ \\
\hline 4 & Test set molecule & ${ }^{\mathrm{a} D H P}$ & 0.019 & $\mathrm{C}_{20} \mathrm{H}_{30} \mathrm{O}_{4}$ \\
\hline 5 & template molecule & ${ }^{\mathrm{a} D M P}$ & 0.220 & $\mathrm{C}_{10} \mathrm{H}_{10} \mathrm{O}_{4}$ \\
\hline 6 & Test set molecule & ${ }^{\mathrm{b}} \mathrm{DAP}$ & 0.155 & $\mathrm{C}_{14} \mathrm{H}_{14} \mathrm{O}_{4}$ \\
\hline 7 & Training set molecule & bDIBP & 0.322 & $\mathrm{C}_{16} \mathrm{H}_{22} \mathrm{O}_{4}$ \\
\hline 8 & Training set molecule & bIHP & $0.276 \times 10^{-2}$ & $\mathrm{C}_{22} \mathrm{H}_{34} \mathrm{O}_{4}$ \\
\hline 9 & & ${ }^{b} \mathrm{DIHXP}$ & $0.057 \times 10^{-1}$ & $\mathrm{C}_{20} \mathrm{H}_{30} \mathrm{O}_{4}$ \\
\hline 10 & Training set molecule & ${ }^{\mathrm{b}} \mathrm{DIPP}$ & $0.638 \times 10^{-5}$ & $\mathrm{C}_{18} \mathrm{H}_{26} \mathrm{O}_{4}$ \\
\hline 11 & & ${ }^{b}$ DIPRP & 0.351 & $\mathrm{C}_{14} \mathrm{H}_{18} \mathrm{O}_{4}$ \\
\hline 12 & Training set molecule & ${ }^{b} \mathrm{DMEP}$ & $0.303 \times 10^{-1}$ & $\mathrm{C}_{14} \mathrm{H}_{18} \mathrm{O}_{6}$ \\
\hline 13 & Training set molecule & ${ }^{\mathrm{b}} \mathrm{DNOP}$ & $0.194 \times 10^{-3}$ & $\mathrm{C}_{24} \mathrm{H}_{38} \mathrm{O}_{4}$ \\
\hline 14 & Training set molecule & ${ }^{\mathrm{b}} \mathrm{DPP}$ & $0.261 \times 10^{-1}$ & $\mathrm{C}_{18} \mathrm{H}_{26} \mathrm{O}_{4}$ \\
\hline 15 & Test set molecule & ${ }^{\mathrm{b}} \mathrm{DPRP}$ & 0.102 & $\mathrm{C}_{14} \mathrm{H}_{18} \mathrm{O}_{4}$ \\
\hline 16 & Training set molecule & ${ }^{\mathrm{b}} \mathrm{DTDP}$ & $0.335 \times 10^{-8}$ & $\mathrm{C}_{34} \mathrm{H}_{58} \mathrm{O}_{4}$ \\
\hline 17 & Training set molecule & ${ }^{\mathrm{b} D U P}$ & $0.163 \times 10^{-6}$ & $\mathrm{C}_{31} \mathrm{H}_{52} \mathrm{O}_{4}$ \\
\hline
\end{tabular}

$\mathrm{a}$ is the vapor pressure value of the molecule from the literature, $\mathrm{b}$ is the vapor pressure value of the molecule from the EPI prediction. 
Table 2. Evaluation parameters of PAE molecular volatility CoMSIA model.

\begin{tabular}{|c|c|c|c|c|c|c|c|c|c|c|}
\hline Model & $\mathrm{q}^{2}$ & $\mathrm{n}$ & $\mathrm{SEE}$ & $\mathrm{R}^{2}$ & $\mathrm{~F}$ & $\mathrm{r}_{\text {pred }}^{2}$ & SEP & $\mathrm{Q}^{2}$ & $\mathrm{cSDEP}$ & $\mathrm{dq}^{2} / \mathrm{dr}^{2} \mathrm{yy}$ \\
\hline CoMSIA & 0.783 & 8 & 0.010 & 0.998 & 186.087 & 0.532 & 0.071 & 0.396 & 0.169 & 2.912 \\
\hline
\end{tabular}

bond donor field were $23.00 \%, 33.10 \%, 28.20 \%, 0.00 \%$, and $15.70 \%$, respectively. This shows that the electrical distribution, hydrophobicity, and spatial effect of the groups are the main factors affecting the volatility of PAE homologs.

\section{Modification of Target Molecule Based on CoMSIA Model of PAEs}

As Fig. 1 shows, DMP template molecules were used to analyze the three-dimensional potentiometric map of PAE molecules. In the electrostatic field, the introduction of both, negative charge groups into the blue area or positive charge groups into the red area, was beneficial in reducing the volatility of compounds. In the hydrophobic field, hydrophilic groups were introduced in the yellow area or hydrophobic groups were introduced in the white area to reduce the volatility of compounds. In the steric field, because the modification site is $-\mathrm{CH}_{3}$ and there is no group with a smaller relative molecular weight than $-\mathrm{CH}_{3}$, the effect of the three-dimensional field is not considered.

To sum up, as shown in Fig. 2, in order to reduce the volatility of compounds, negative charge groups can be introduced at site 1 and hydrophilic groups can be introduced at site 1' for molecular modification.

In this study, by analyzing the three-dimensional potentiometric map of the CoMSIA model and determining the modification site of the target molecule, 11 negative-charge groups were selected as the modifying groups to modify site 1 of the DMP molecule: these groups were ethyl $\left(-\mathrm{CH}_{2} \mathrm{CH}_{3}\right)$, phenyl $\left(-\mathrm{C}_{6} \mathrm{H}_{5}\right)$, aldehyde $(-\mathrm{CHO})$, carboxyl $(-\mathrm{COOH})$, methoxy $\left(-\mathrm{OCH}_{3}\right)$, silicon alkyl $\left(-\mathrm{SiH}_{3}\right)$, hydroxyl $(-\mathrm{OH})$, formyl oxygen radicals (-OCHO), acetoxyl $\left(-\mathrm{OCOCH}_{3}\right)$, sulfhydryl (-SH) and amino $\left(-\mathrm{NH}_{2}\right)$. In addition, four hydrophilic groups were selected as modifying groups to modify site 1' of the DMP molecule: these groups<smiles>C#COC(=O)c1ccccc1C(=O)OC#N</smiles>

Fig. 2. Selection of molecular modification sites for PAE derivatives.

were hydroxyl (-OH), aldehyde (-CHO), carboxyl $(-\mathrm{COOH})$, and amino $\left(-\mathrm{NH}_{2}\right)$.

\section{Prediction and Evaluation of Molecular Volatility of PAE Derivatives}

The CoMSIA model was used to modify site 1 of PAEs molecule DMP, as well as site 1 and site 1' at the same time, and 11 single substituted derivatives and 44 disubstituted derivatives were obtained. The predicted volatility and the rate of change are listed in Table 3.

As shown in Table 3, among the 11 derivatives modified by the mono-substitution reaction at site 1 of the DMP, seven derivatives had a lower volatile value than the target molecule; further, the five derivatives of them, namely, DMP-2, DMP-4, DMP-6, DMP-8, and DMP-9 had a modified effect higher than $10 \%$, and there was a $14.55 \%$ to $25.91 \%$ decrease in their rate of volatility compared than DMP. Among the 44 derivatives modified by the disubstituted reaction at sites 1 and 1' of DMP, thirty derivatives had lower a volatile value than the target molecule; further, the fourteen derivatives of them, namely, DMP-12,
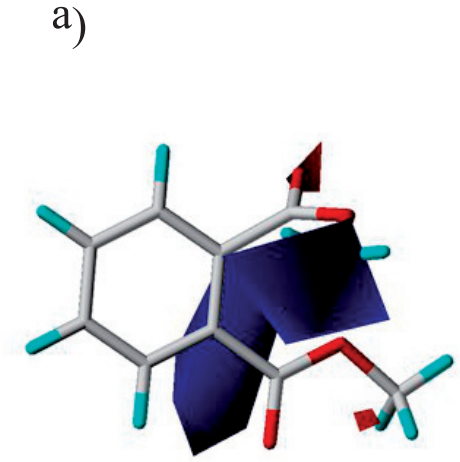

b)
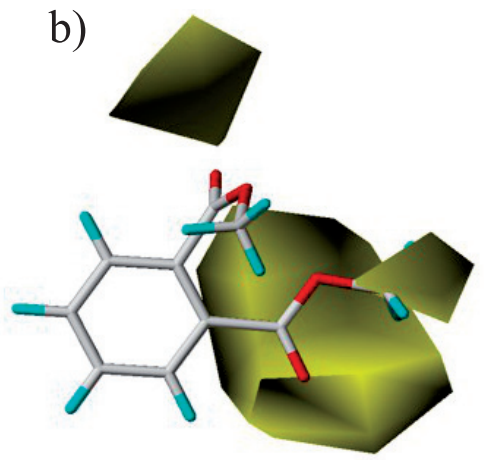

Fig. 1. Contour maps of the CoMSIA model: a) electrostatic fields; b) hydrophobic fields. 
Table 3. Predicted value and rate of change of Volatile CoMSIA model of PAE derivatives.

\begin{tabular}{|c|c|c|c|c|c|}
\hline \multirow{2}{*}{\multicolumn{2}{|c|}{ PAEs }} & \multicolumn{2}{|c|}{ Replace the site } & \multicolumn{2}{|c|}{ Volatility } \\
\hline & & \multirow{2}{*}{$\frac{\text { Site } 1}{-}$} & \multirow{2}{*}{$\frac{\text { Site 1' }}{-}$} & \multirow{2}{*}{$\frac{\text { Predicted value }(\mathrm{Pa})}{0.220}$} & \multirow{2}{*}{$\frac{\text { Change rate }(\%)}{-}$} \\
\hline Target & DMP & & & & \\
\hline \multirow{11}{*}{ Single substituted reaction } & DMP-1 & $-\mathrm{CH}_{2} \mathrm{CH}_{3}$ & - & 0.215 & -2.27 \\
\hline & DMP-2 & $-\mathrm{C}_{6} \mathrm{H}_{5}$ & - & 0.163 & -25.91 \\
\hline & DMP-3 & $-\mathrm{CHO}$ & - & 0.232 & 5.45 \\
\hline & DMP-4 & $-\mathrm{COOH}$ & - & 0.114 & -48.18 \\
\hline & DMP-5 & $-\mathrm{OCH}_{3}$ & - & 0.244 & 10.91 \\
\hline & DMP-6 & $-\mathrm{SiH}_{3}$ & - & 0.188 & -14.55 \\
\hline & DMP-7 & $-\mathrm{OH}$ & - & 0.249 & 13.18 \\
\hline & DMP-8 & -OCHO & - & 0.186 & -15.45 \\
\hline & DMP-9 & $-\mathrm{OCOCH}_{3}$ & - & 0.169 & -23.18 \\
\hline & DMP-10 & $-\mathrm{SH}$ & - & 0.204 & -7.27 \\
\hline & DMP-11 & $-\mathrm{NH}_{2}$ & - & 0.274 & 24.55 \\
\hline \multirow{27}{*}{ Disubstituted reaction } & DMP-12 & $-\mathrm{CH}_{2} \mathrm{CH}_{3}$ & $-\mathrm{OH}$ & 0.165 & -25.00 \\
\hline & DMP-13 & $-\mathrm{CH}_{2} \mathrm{CH}_{3}$ & $-\mathrm{CHO}$ & 0.219 & -0.45 \\
\hline & DMP-14 & $-\mathrm{CH}_{2} \mathrm{CH}_{3}$ & $-\mathrm{COOH}$ & 0.148 & -32.73 \\
\hline & DMP-15 & $-\mathrm{CH}_{2} \mathrm{CH}_{3}$ & $-\mathrm{NH}_{2}$ & 0.183 & -16.82 \\
\hline & DMP-16 & $-\mathrm{C}_{6} \mathrm{H}_{5}$ & $-\mathrm{OH}$ & 0.206 & -6.36 \\
\hline & DMP-17 & $-\mathrm{C}_{6} \mathrm{H}_{5}$ & $-\mathrm{CHO}$ & 0.150 & -31.82 \\
\hline & DMP-18 & $-\mathrm{C}_{6} \mathrm{H}_{5}$ & $-\mathrm{COOH}$ & 0.154 & -30.00 \\
\hline & DMP-19 & $-\mathrm{C}_{6} \mathrm{H}_{5}$ & $-\mathrm{NH}_{2}$ & 0.174 & -20.91 \\
\hline & DMP-20 & $-\mathrm{CHO}$ & $-\mathrm{OH}$ & 0.197 & -10.45 \\
\hline & DMP-21 & $-\mathrm{CHO}$ & $-\mathrm{CHO}$ & 0.211 & -4.09 \\
\hline & DMP-22 & $-\mathrm{CHO}$ & $-\mathrm{COOH}$ & 0.199 & -9.55 \\
\hline & DMP-23 & $-\mathrm{CHO}$ & $-\mathrm{NH}_{2}$ & 0.228 & 3.64 \\
\hline & DMP-24 & -COOH & $-\mathrm{OH}$ & 0.243 & 10.45 \\
\hline & DMP-25 & $-\mathrm{COOH}$ & $-\mathrm{CHO}$ & 0.278 & 26.36 \\
\hline & DMP-26 & $-\mathrm{COOH}$ & $-\mathrm{COOH}$ & 0.208 & -5.45 \\
\hline & DMP-27 & -COOH & $-\mathrm{NH}_{2}$ & 0.219 & -0.45 \\
\hline & DMP-28 & $-\mathrm{OCH}_{3}$ & $-\mathrm{OH}$ & 0.202 & 8.18 \\
\hline & DMP-39 & $-\mathrm{OCH}_{3}$ & $-\mathrm{CHO}$ & 0.229 & 4.09 \\
\hline & DMP-30 & $-\mathrm{OCH}_{3}$ & $-\mathrm{COOH}$ & 0.189 & -14.09 \\
\hline & DMP-31 & $-\mathrm{OCH}_{3}$ & $-\mathrm{NH}_{2}$ & 0.195 & -11.36 \\
\hline & DMP-32 & $-\mathrm{SiH}_{3}$ & $-\mathrm{OH}$ & 0.217 & -1.36 \\
\hline & DMP-33 & $-\mathrm{SiH}_{3}$ & $-\mathrm{CHO}$ & 0.201 & -8.64 \\
\hline & DMP-34 & $-\mathrm{SiH}_{3}$ & $-\mathrm{COOH}$ & 0.214 & -2.73 \\
\hline & DMP-35 & $-\mathrm{SiH}_{3}$ & $-\mathrm{NH}_{2}$ & 0.197 & -10.45 \\
\hline & DMP-36 & $-\mathrm{OH}$ & $-\mathrm{OH}$ & 0.224 & -1.82 \\
\hline & DMP-37 & $-\mathrm{OH}$ & $-\mathrm{CHO}$ & 0.248 & 12.73 \\
\hline & DMP-38 & $-\mathrm{OH}$ & $-\mathrm{COOH}$ & 0.243 & 10.45 \\
\hline
\end{tabular}


Table 3. Continued.

\begin{tabular}{|c|c|c|c|c|c|}
\hline \multirow{17}{*}{ Disubstituted reaction } & DMP-39 & $-\mathrm{OH}$ & $-\mathrm{NH}_{2}$ & 0.219 & -0.45 \\
\hline & DMP-40 & -OCHO & $-\mathrm{OH}$ & 0.210 & -4.55 \\
\hline & DMP-41 & -OCHO & $-\mathrm{CHO}$ & 0.231 & 5.00 \\
\hline & DMP-42 & -OCHO & $-\mathrm{COOH}$ & 0.222 & 0.91 \\
\hline & DMP-43 & $-\mathrm{OCHO}$ & $-\mathrm{NH}_{2}$ & 0.211 & -4.09 \\
\hline & DMP-44 & $-\mathrm{OCOCH}_{3}$ & $-\mathrm{OH}$ & 0.164 & -25.45 \\
\hline & DMP-45 & $-\mathrm{OCOCH}_{3}$ & $-\mathrm{CHO}$ & 0.260 & 18.18 \\
\hline & DMP-46 & $-\mathrm{OCOCH}_{3}$ & $-\mathrm{COOH}$ & 0.117 & -46.82 \\
\hline & DMP-47 & $-\mathrm{OCOCH}_{3}$ & $-\mathrm{NH}_{2}$ & 0.158 & -28.18 \\
\hline & DMP-48 & $-\mathrm{SH}$ & $-\mathrm{OH}$ & 0.201 & -8.64 \\
\hline & DMP-49 & $-\mathrm{SH}$ & $-\mathrm{CHO}$ & 0.189 & -14.09 \\
\hline & DMP-50 & $-\mathrm{SH}$ & $-\mathrm{COOH}$ & 0.216 & -1.82 \\
\hline & DMP-51 & $-\mathrm{SH}$ & $-\mathrm{NH}_{2}$ & 0.235 & 6.82 \\
\hline & DMP-52 & $-\mathrm{NH}_{2}$ & $-\mathrm{OH}$ & 0.230 & 4.55 \\
\hline & DMP-53 & $-\mathrm{NH}_{2}$ & $-\mathrm{CHO}$ & 0.228 & 3.64 \\
\hline & DMP-54 & $-\mathrm{NH}_{2}$ & $-\mathrm{COOH}$ & 0.219 & -0.45 \\
\hline & DMP-55 & $-\mathrm{NH}_{2}$ & $-\mathrm{NH}_{2}$ & 0.235 & 6.82 \\
\hline
\end{tabular}

DMP-14, DMP-15, DMP-17, DMP-18, DMP-19, DMP20, DMP-30, DMP-31, DMP-35, DMP-44, DMP-46, DMP-47, and DMP-49 had a modified effect higher than $10 \%$, and there was a $10.45 \%$ to $48.18 \%$ decrease in their rate of volatility compared than DMP.

In summary, 37 PAE derivatives with significantly reduced volatility were designed based on single substituted and disubstituted reactions. In this study, 19 PAE derivatives whose modification effect was higher than $10 \%$ were selected as research objects for evaluation of their environmental friendliness.

\section{Environmental Friendliness and Functional Evaluation of PAE Derivatives}

The PAE molecular toxicity, persistence, and bioenrichment model constructed by Qiu et al. [22] was used to predict the environmental friendliness of the 19 PAE molecular derivatives. The toxicity, persistence, and bio-enrichment were used as indicators to characterize the environmental friendliness of PAE before and after molecular modification. The specific evaluation parameters are listed in Table 4.

As Table 4 shows, as per the PAE model prediction results, the following 12 derivatives show lower molecular toxicity between $31.34 \%$ and $37.12 \%$ ( $\mathrm{LC}_{50}$ value is higher): DMP-4, DMP-6, DMP8, DMP-9, DMP-20, DMP-30, DMP-31, DMP-35, DMP-44, DMP-46, DMP-47, and DMP-49. Further, seven derivatives show higher molecular toxicity $\left(\mathrm{LC}_{50}\right.$ value is lower), so they do not conform to the standards for environmental friendliness. The prediction results of the PAE persistence model show that the $\log t_{1 / 2}$ values of the following 11 PAE derivative molecules are lower: DMP-2, DMP-4, DMP-6, DMP-8, DMP9, DMP-12, DMP-14, DMP-35, DMP-44, DMP46, and DMP-47; it is speculated that the lifetime is reduced in the environment. The persistence values of the remaining eight derivatives are higher and do not meet the requirements of environmental friendliness. These results indicate that seven PAE derivatives met the requirements of low toxicity and low persistence: DMP-4, DMP-6, DMP-8, DMP-9, DMP-44, DMP-46, and DMP-47. Further, the prediction of the PAE bioenrichment model shows that the $\log B C F$ values of these seven are higher (with different values). According to Dacies et al. [41], when the $\log B C F$ value is less than 3 , the impact on the environment is negligible. The $\log B C F$ values of these seven derivatives are between 0.735 and 1.136 , so they all meet the requirements of low bio-enrichment.

The functional characteristics of PAE derivatives were characterized on the basis of their total energy, energy gap, and frequency, and the Gaussian software was used for calculations (Table 5). As Table 5 shows, the molecular total energy values of the seven DMP derivatives were all lower than that of DMP, by $30.42 \%$, $36.55 \%, 21.68 \%, 27.40 \%, 32.60 \%, 49.09 \%$, and $29.72 \%$, indicating that the stability of the designed DMP derivatives in the environment was higher than that of the target molecule. In addition, the energy gap values of the seven DMP derivatives remained nearly the same as that of DMP, with a deviation of only about $3 \%$ (from $-1.30 \%$ to $2.40 \%$ ), indicating that the insulation 
Table 4. Evaluation of environmental friendliness of PAE derivatives.

\begin{tabular}{|c|c|c|c|c|c|c|c|c|c|}
\hline \multirow{2}{*}{\multicolumn{2}{|c|}{ PAEs }} & \multicolumn{2}{|c|}{ Replace the site } & \multicolumn{2}{|c|}{ Biotoxicity $\left(\mathrm{LC}_{50}\right)$} & \multicolumn{2}{|c|}{ Persistence $\left(\log t_{1 / 2}\right)$} & \multicolumn{2}{|c|}{$\begin{array}{l}\text { Bio-enrichment } \\
\quad(\log B C F)\end{array}$} \\
\hline & & \multirow{2}{*}{$\frac{\text { Site } 1}{-}$} & \multirow{2}{*}{$\frac{\text { Site 1' }}{-}$} & \multirow{2}{*}{\begin{tabular}{|c|}
$\begin{array}{c}\text { Predicted } \\
\text { value }\end{array}$ \\
40.822 \\
\end{tabular}} & \multirow{2}{*}{$\begin{array}{l}\text { Change } \\
\text { rate }(\%) \\
-\end{array}$} & \multirow{2}{*}{$\begin{array}{c}\begin{array}{c}\text { Predicted } \\
\text { value }\end{array} \\
3.620\end{array}$} & \multirow{2}{*}{$\begin{array}{l}\text { Change } \\
\text { rate }(\%) \\
-\end{array}$} & \multirow{2}{*}{$\begin{array}{c}\begin{array}{c}\text { Predicted } \\
\text { value }\end{array} \\
0.723\end{array}$} & \multirow{2}{*}{$\begin{array}{c}\text { Change } \\
\text { rate }(\%) \\
-\end{array}$} \\
\hline Target & DMP & & & & & & & & \\
\hline \multirow{5}{*}{$\begin{array}{l}\text { Single } \\
\text { substituted } \\
\text { reaction }\end{array}$} & DMP-2 & $-\mathrm{C}_{6} \mathrm{H}_{5}$ & - & 1.031 & -97.47 & 3.259 & -9.98 & - & - \\
\hline & DMP-4 & $-\mathrm{COOH}$ & - & 53.993 & 32.27 & 3.556 & -1.76 & 1.012 & 39.97 \\
\hline & DMP-6 & $-\mathrm{SiH}_{3}$ & - & 54.628 & 33.82 & 3.323 & -8.20 & 0.823 & 13.83 \\
\hline & DMP-8 & -OCHO & - & 53.920 & 32.09 & 2.798 & -22.71 & 0.735 & 9.98 \\
\hline & DMP-9 & $-\mathrm{OCOCH}_{3}$ & - & 53.669 & 31.47 & 2.845 & -21.41 & 0.908 & 1.66 \\
\hline \multirow{14}{*}{$\begin{array}{l}\text { Disubstituted } \\
\text { reaction }\end{array}$} & DMP-12 & $-\mathrm{CH}_{2} \mathrm{CH}_{3}$ & $-\mathrm{OH}$ & 7.832 & -80.82 & 2.652 & -26.75 & - & - \\
\hline & DMP-14 & $-\mathrm{CH}_{2} \mathrm{CH}_{3}$ & $-\mathrm{COOH}$ & 4.317 & -89.43 & 2.624 & -27.52 & - & - \\
\hline & DMP-15 & $-\mathrm{CH}_{2} \mathrm{CH}_{3}$ & $-\mathrm{NH}_{2}$ & 9.769 & -76.07 & 4.299 & 18.75 & - & - \\
\hline & DMP-17 & $-\mathrm{C}_{6} \mathrm{H}_{5}$ & $-\mathrm{CHO}$ & 1.569 & -96.16 & 5.167 & 42.73 & - & - \\
\hline & DMP-18 & $-\mathrm{C}_{6} \mathrm{H}_{5}$ & $-\mathrm{COOH}$ & 1.930 & -95.27 & 8.107 & 123.95 & - & - \\
\hline & DMP-19 & $-\mathrm{C}_{6} \mathrm{H}_{5}$ & $-\mathrm{NH}_{2}$ & 1.899 & -95.37 & 6.060 & 67.40 & - & - \\
\hline & DMP-20 & $-\mathrm{CHO}$ & $-\mathrm{OH}$ & 53.909 & 32.06 & 5.833 & 61.13 & - & - \\
\hline & DMP-30 & $-\mathrm{OCH}_{3}$ & $-\mathrm{COOH}$ & 53.662 & 31.45 & 7.183 & 98.41 & - & - \\
\hline & DMP-31 & $-\mathrm{OCH}_{3}$ & $-\mathrm{NH}_{2}$ & 53.622 & 31.35 & 7.328 & 102.31 & - & - \\
\hline & DMP-35 & $-\mathrm{SiH}_{3}$ & $-\mathrm{NH}_{2}$ & 55.975 & 37.12 & 3.860 & -6.64 & - & - \\
\hline & DMP-44 & $-\mathrm{OCOCH}_{3}$ & $-\mathrm{OH}$ & 53.617 & 31.34 & 2.867 & -20.80 & 1.075 & 48.69 \\
\hline & DMP-46 & $-\mathrm{OCOCH}_{3}$ & $-\mathrm{COOH}$ & 53.643 & 31.41 & 2.968 & -18.01 & 1.136 & 57.12 \\
\hline & DMP-47 & $-\mathrm{OCOCH}_{3}$ & $-\mathrm{NH}_{2}$ & 53.656 & 31.44 & 2.862 & -20.93 & 1.101 & 52.28 \\
\hline & DMP-49 & $-\mathrm{SH}$ & $-\mathrm{CHO}$ & 53.664 & 31.46 & 6.004 & 65.85 & - & - \\
\hline
\end{tabular}

Table 5. Evaluation of molecular functionality of PAE derivatives.

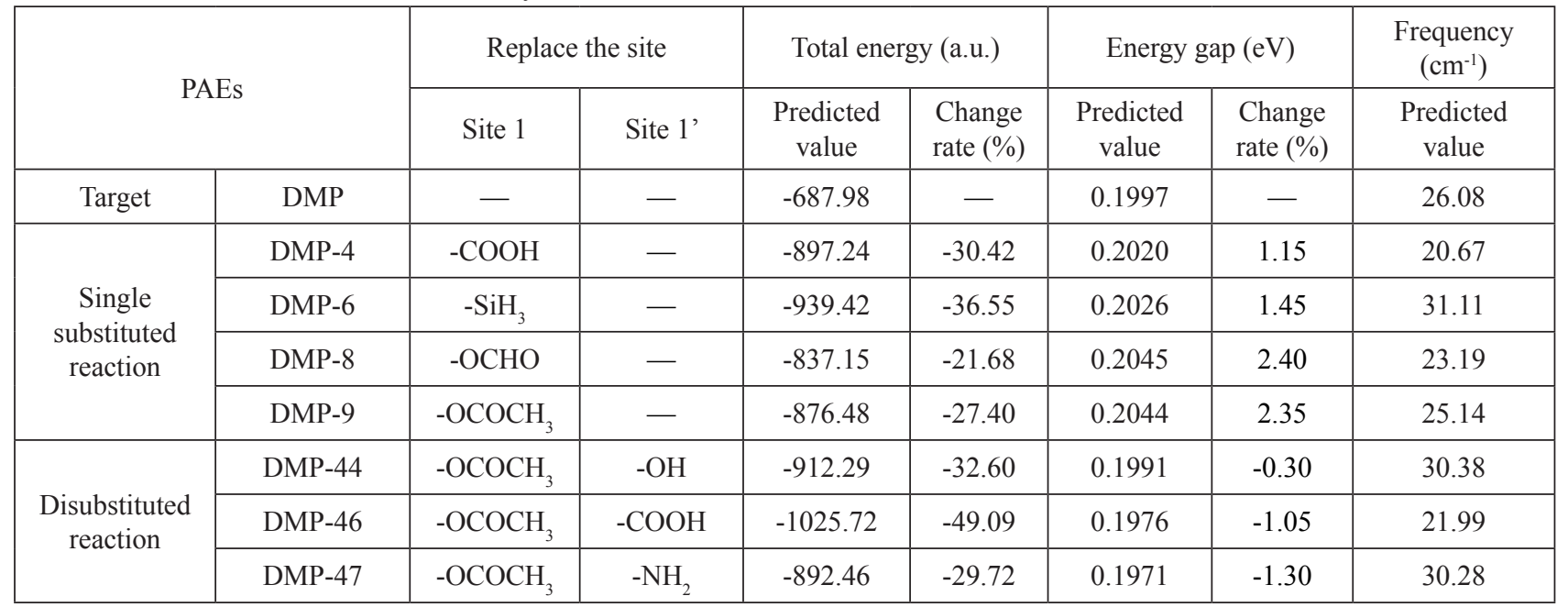

performance of the modified derivatives remained nearly unchanged. The frequency values of the seven DMP derivatives were all greater than 0 , so the newly designed DMP derivatives could theoretically exist stably in the environment [33]. 
Table 6. The contribution of elements and chemical bonds to volume.

\begin{tabular}{|c|c|c|c|}
\hline Element & $\begin{array}{c}\text { Volume } \\
\left(\mathrm{cm}^{3} \cdot \mathrm{mol}^{-1}\right)\end{array}$ & $\begin{array}{c}\text { Chemical } \\
\text { bond }\end{array}$ & $\begin{array}{c}\text { Volume } \\
\left(\mathrm{cm}^{3} \cdot \mathrm{mol}^{-1}\right)\end{array}$ \\
\hline $\mathrm{C}$ & 12.39 & $\mathrm{C}-\mathrm{C}$ & -4.30 \\
\hline $\mathrm{H}$ & 4.36 & $\mathrm{C}-\mathrm{O}$ & -4.82 \\
\hline $\mathrm{O}$ & 8.51 & $\mathrm{C}=\mathrm{O}$ & -4.87 \\
\hline $\mathrm{N}$ & 9.39 & $\mathrm{C}-\mathrm{H}$ & -3.17 \\
\hline $\mathrm{S}$ & 14.70 & $\mathrm{Si}-\mathrm{O}$ & -2.99 \\
\hline $\mathrm{Si}$ & 23.35 & $\mathrm{Si}-\mathrm{H}$ & -3.75 \\
\hline- & - & $\mathrm{S}-\mathrm{O}$ & -3.33 \\
\hline- & - & $\mathrm{S}-\mathrm{H}$ & -2.04 \\
\hline- & - & $\mathrm{N}-\mathrm{O}$ & -3.47 \\
\hline- & - & $\mathrm{N}-\mathrm{H}$ & -2.95 \\
\hline- & - & $\mathrm{O}-\mathrm{O}$ & -6.18 \\
\hline- & - & $\mathrm{O}-\mathrm{H}$ & -2.59 \\
\hline- & - & $\mathrm{N}$ & -30.67 \\
\hline
\end{tabular}

Table 7. DMP molecular volume calculation parameters.

\begin{tabular}{|c|c|c|}
\hline $\begin{array}{c}\text { Element and } \\
\text { Chemical bond }\end{array}$ & number & $\begin{array}{c}\text { Volume } \\
\left(\mathrm{cm}^{3} \cdot \mathrm{mol}^{-1}\right)\end{array}$ \\
\hline $\mathrm{C}$ & 10 & 12.39 \\
\hline $\mathrm{H}$ & 10 & 4.36 \\
\hline $\mathrm{O}$ & 4 & 8.51 \\
\hline $\mathrm{C}-\mathrm{C}$ & 2 & -4.30 \\
\hline $\mathrm{C}-\mathrm{O}$ & 4 & -4.82 \\
\hline $\mathrm{C}=\mathrm{O}$ & 2 & -4.87 \\
\hline $\mathrm{C}-\mathrm{H}$ & 6 & -3.17 \\
\hline & 1 & -30.67 \\
\hline
\end{tabular}

\section{Analysis of Molecular Stability Enhancement of DMP Derivatives Based on Element and Chemical-Bond Contributions}

The relative molecular mass of the plasticizer affects its mobility and diffusion rate in the polymer when the larger relative molecular weight of plasticizer is; it has larger molecular group volume and less easy to jump in the polymer hoes [42]. The larger the relative molecular weight, the more difficult it is for the molecules to diffuse in the plastic products; further, if the amount of plasticizer reaching the plastic surface is low, the volatilization from the plastic surface and the migration probability will be low [43].

In this study, the method based on the element and chemical-bond contributions was used to calculate the volume of PAE derivative molecules [44]. This method considers the contribution of the elements and their interactions (chemical bonds) to the molecular volume. The molecular volume is calculated by taking elements and chemical bonds as the basic units of contribution. The element volume contribution value and chemical bond volume contribution value used in this method are derived from the study of $\mathrm{Hu}$ et al. [45] and Zhao et al. [44], and the specific volume results are listed in Table 6.

The sum of the contribution values of elements and chemical bonds is the volume of molecules; the relevant formula is as follows:

$$
P=\sum_{\mathrm{i}} \mathrm{m}_{\mathrm{i}} \cdot \mathrm{p}_{\mathrm{i}}+\sum_{\mathrm{j}} \mathrm{m}_{\mathrm{j}} \cdot \mathrm{p}_{\mathrm{j}}
$$

$\mathrm{P}$ is the molecular volume, $\mathrm{i}$ is the element in the molecule, $\mathrm{j}$ is the chemical bond in the molecule, $\mathrm{M}$ is the number of elements or chemical bonds, and $\mathrm{p}$ is the volume contribution value of the element or chemical bond. In the case of the target molecule DMP, for example, its volume is $114.23 \mathrm{~cm}^{3} \cdot \mathrm{mol}^{-1}$ according to formula (1). The specific calculation parameters are shown in Table 7.

Table 8. Calculation result of molecular volume and relative molecular mass of PAE derivatives.

\begin{tabular}{|c|c|c|c|c|c|c|c|}
\hline \multirow{2}{*}{ PAEs } & \multicolumn{2}{|c|}{ The group at the site } & \multirow{2}{*}{$\begin{array}{c}\text { Volume } \\
\left(\mathrm{cm}^{3} \cdot \mathrm{mol}^{-1}\right)\end{array}$} & \multirow{2}{*}{$\begin{array}{c}\text { Change rate } \\
(\%)\end{array}$} & \multirow{2}{*}{ Formula } & \multirow{2}{*}{$\begin{array}{l}\text { Relative mo- } \\
\text { lecular mass }\end{array}$} & \multirow{2}{*}{$\begin{array}{c}\text { Change rate } \\
(\%)\end{array}$} \\
\hline & Site 1 & Site 1' & & & & & \\
\hline DMP & $-\mathrm{CH}_{3}$ & $-\mathrm{CH}_{3}$ & 114.23 & - & $\mathrm{C}_{10} \mathrm{H}_{10} \mathrm{O}_{4}$ & 194 & - \\
\hline DMP-4 & $-\mathrm{COOH}$ & $-\mathrm{CH}_{3}$ & 119.18 & 4.33 & $\mathrm{C}_{10} \mathrm{H}_{8} \mathrm{O}_{6}$ & 224 & 15.46 \\
\hline DMP-6 & $-\mathrm{SiH}_{3}$ & $-\mathrm{CH}_{3}$ & 125.28 & 9.67 & $\mathrm{C}_{9} \mathrm{H}_{10} \mathrm{O}_{4} \mathrm{Si}$ & 210 & 8.25 \\
\hline DMP-8 & -OCHO & $-\mathrm{CH}_{3}$ & 117.82 & 3.14 & $\mathrm{C}_{10} \mathrm{H}_{8} \mathrm{O}_{6}$ & 224 & 15.46 \\
\hline DMP-9 & $-\mathrm{OCOCH}_{3}$ & $-\mathrm{CH}_{3}$ & 129.13 & 13.04 & $\mathrm{C}_{10} \mathrm{H}_{11} \mathrm{O}_{6}$ & 238 & 22.68 \\
\hline DMP-44 & $-\mathrm{OCOCH}_{3}$ & $-\mathrm{OH}$ & 122.09 & 6.89 & $\mathrm{C}_{9} \mathrm{H}_{9} \mathrm{O}_{7}$ & 240 & 23.71 \\
\hline DMP-46 & $-\mathrm{OCOCH}_{3}$ & $-\mathrm{COOH}$ & 134.08 & 17.37 & $\mathrm{C}_{10} \mathrm{H}_{9} \mathrm{O}_{8}$ & 268 & 38.14 \\
\hline DMP-47 & $-\mathrm{OCOCH}_{3}$ & $-\mathrm{NH}_{2}$ & 126.73 & 10.94 & $\mathrm{C}_{9} \mathrm{H}_{10} \mathrm{NO}_{6}$ & 239 & 23.20 \\
\hline
\end{tabular}


By using formula (1), the volume of the seven derivatives was calculated, and the relative molecular mass of each atom in the molecular formula was calculated. The calculation results are shown in Table 8.

As shown in Table 8, the molecular volume of the seven PAE derivatives increased by $4.33 \%, 9.67 \%$, $3.14 \%, 3.04 \%, 6.89 \%, 17.37 \%$, and $10.94 \%$, respectively. Further, their relative molecular weights increased by $15.46 \%, 8.25 \%, 15.46 \%, 22.68 \%, 23.71 \%, 38.14 \%$, and $23.20 \%$, respectively. The results showed that the modified DMP molecules were less likely to diffuse and migrate in the plastic than the target molecules before modification.

In summary, after the modification of DMP molecules with a larger molecular weight and volume, the resultant derivative molecules inhibit the migration of the plasticizer to the environment. Thus the plasticizer stays in the plastic, indicating improved plasticizer stability and plastic elasticity, flexibility, and workability. In this way, the plastic's resistance against deterioration - such as the plastic turning hard, brittle, or yellow, or a decrease in the air permeability and moisture permeability due to loss of plasticizer - is increased.

\section{Conclusions}

In this study, by constructing the 3D-QSAR model with PAE volatility as the evaluation index and by applying the comprehensive evaluation model that considers environmental friendliness, the following seven environmentally friendly PAE derivatives with enhanced stability were designed and selected: DMP$\mathrm{COOH}, \mathrm{DMP}-\mathrm{SiH}, \mathrm{DMP}-\mathrm{OCHO}$, DMP-OCOCH${ }_{3}$, $\mathrm{DMP}-\mathrm{OCOCH}-\mathrm{OH}_{3}, \quad \mathrm{DMP}_{-} \mathrm{OCOCH}_{3}-\mathrm{COOH}, \quad$ and DMP-OCOCH $-\mathrm{NH}_{2}$. Their volatility was $48.18 \%$, $14.55 \%, 15.45 \%, 23.18 \%, 25.45 \%, 46.82 \%$, and $28.18 \%$ lower, respectively, than that of DMP, and their toxicity was $32.27 \%, 33.82 \%, 32.09 \%, 31.47 \%, 31.34 \%, 31.41 \%$, and $31.44 \%$ lower, respectively. In addition, their persistence was $1.76 \%, 8.20 \%, 22.71 \%, 21.41 \%, 20.80 \%$, $18.01 \%$, and $20.93 \%$ lower, respectively. All of their bio-enrichment meet the requirements of environmental friendliness.

Moreover, the method based on elemental and chemical-bond contribution was used to calculate the volume of the derivatives. The mechanism of inhibiting plasticizer migration and diffusion is explained from two aspects of volume change and relative-molecularweight change of derivatives. It is clarified that the new PAE derivatives are less prone to volatilization and migration, and that they can improve the stability of plastic products. This study thus provides a theoretical foundation for the replacement of PAE plasticizers in the future.

\section{Acknowledgements}

We thank American Journal Experts (http://www. aje.cn/ac) for English language editing. This manuscript was edited for English language by American Journal Experts (AJE).

\section{Conflict of Interest}

The authors declare no conflict of interest.

\section{References}

1. KOELMANS A.A., GOUIN T., THOMPSON R., WALLACE N., ARTHUR C. Plastics in the marine environment. Environ Toxicol Chem, 33, 5, 2014.

2. WAGNER M., SCHERER C., ALVAREZ-MUNOZ D., BRENNHOLT N., BOURRAIN X., BUCHINGER S., FRIES E., GROSBOIS C., KLASMEIER J., MARTI K., RODRIGUEZ-MOZAZ S., URBATZKA R., VETHAAK A., WINTHER-NIELSEN M., REIFFERSCHEID G. Microplastics in fresh water ecosystems, What we know and what we need to know. Environmental Sciences Europe, 2 (1), 12, 2014.

3. LI X.Z., LI L.P., CAO C.H., CHENG J. Migration and inhibition of plasticizer in PVC products. Engineering applications as expected, 47 (5), 148, 2019 [In Chinese].

4. WANG X., YANG Y., ZHANG L., MA Y., HAN J., YANG L., ZHOU B. Endocrine disruption by di- (2-ethylhexyl)phthalate in Chinese rare minnow (Gobiocypris rarus). Environ Toxicol Chem, 32, 1846, 2013.

5. JIA P., MA Y., LU C., MIRZA Z., PEI D. The Effects of Disturbance on Hypothalamus-Pituitary-Thyroid (HPT) Axis in Zebrafish Larvae after Exposure to DEHP. PloS One, DOI, 10.1371/journal.pone. 0155762, 2016.

6. GANI K.M., TYAGI V K., KAZMI A.A. Occurrence of phthalates in aquatic environment and their removal during wastewater treatment processes, a review. Environmental Science and Pollution Research, 24 (21), 17267, 2017.

7. O'BRIEN A., COOPER L. Polymer additive migration to food a direct comparison of experimental data and values calculated from migration models for polypropylene. Food Additives \& Contaminants, 4 (18), 343, 2001.

8. TRAN T.M., KANNAN K. Occurrence of phthalate diesters in particulate and vapor phases in indoor air and implications for human exposure in Albany, New York, USA. Archives of Environmental Contamination and Toxicology, 68 (3), 489, 2015.

9. DAS M.T., GHOSH P., THAKUR I.S. Intake estimates of phthalate esters for South Delhi population based on exposure media assessment. Environmental Pollution, 189, $118,2014$.

10. ZHAO H.M., DU H., LIN J., CHEN X.B., LI Y W., LI H., CAI Q.Y., MO C.H., QIN H.M., WONG M.H. Complete degradation of the endocrine disruptor di- (2-ethylhexyl)phthalate by a novel Agromyces sp. MTO strain and its application to bioremediation of contaminated soil. Science of The Total Environment, 562, 170, 2016.

11. OKUBO T., YOKOYAMA Y., KANO K., SOYA Y., KANO I. Estimation of estrogenic and antiestrogenic activities of selected pesticides by MCF-7 cell proliferation 
assay. Archives of Environmental Contamination \& Toxicology, 46 (4), 445, 2004.

12. COLON I., CARO D., BOURDONY C.J., ROSARIO O. Identification of phthalate esters in the serum of young Puerto Rican girls with premature breast development. Environmental Health Perspectives, 108 (9), 895, 2000.

13. HE P.J., ZHENG Z., ZHANG H., SHAO L.M., TANG Q.Y. PAEs and BPA removal in landfill leachate with Fenton process and its relationship with leachate DOM composition. Science of the Total Environment, 407 (17), 4928, 2009.

14. BERTELSEN R.J., CARLSEN K.C.L., CALAFAT A.M., HOPPIN J.A., HALAND G., MOWINCKEL P., CARLSEN K.H., LOVIK M. Urinary biomarkers for phthalates associated with asthma in Norwegian children. Environmental Health Perspectives, 121 (2), 251, 2013.

15. WANG J.L., YE Y.C., WU W.Z. Comparison of dimethyl phthalate biodegradation by free and immobilized microbial cells. Biomedical and Environmental Sciences, 16 (2), 126, 2003.

16. PAN W.P., KANG Y. Mechanism of plasticizer migration in PVC products and influencing factors of inhibition. Rubber Technology and Equipment, 43 (6), 20, 2017 [In Chinese].

17. STALES C.A., PETERSON D.R., PARKERTON T.F., ADAMS W.J. The environmental fate of phthalate esters, A literature review. Chemosphere, 35 (4), 667, 1997.

18. MARAQA M.A., ZHAO X., LEE J.U., ALLAN F., VOICE T.C. Comparison of nonideal sorption formulations in modeling the transport of phthalate esters through packed soil columns. Journal of Contaminant Hydrology, 125 (1/4), 57, 2011.

19. PEIJNENBURG W.J.G.M., STRUIJS J. Occurrence of phthalate esters in the environment of The Netherlands. Ecotoxicology and Environmental Safety, 63 (2), 204, 2006.

20. HOWARD P.H., BANERJEE S., ROBILLARD K.H. Measurement of water solubilities, octanol/water partition coefficients and vapor pressures of commercial phthalate esters. Environmental Toxicology and Chemistry, 4 (5), 653, 1985.

21. KHABEEV N.S., SHAGAPOV V.S., YUMAGULOVA Y.A., BAILEY S.S. Evolution of vapor pressure at contact with liquid. Acta Astronautica, 114, 147, 2015.

22. QIU Y., JIANG L., ZHANG S., LI Y. Molecular design of lower-estrogen-activity phthalate esters with high fluorescence intensity using pharmacophore mode. International Journal of Environmental Analytical Chemistry, DOI, 10.1080/03067319.2019.1673742, 2019.

23. HAN J., YANG L., DU M., LI Y. A novel pharmacophore model on PAEs' estrogen and thyroid hormone activities using the TOPSIS and its application in molecule modification. Environmental Science and Pollution Rsearch, 27, 38805, 2020.

24. LI Q., QIU Y., LI Y. Molecular Design of EnvironmentFriendly PAE Derivatives Based on 3D-QSAR Assisted with a Comprehensive Evaluation Method Combining Toxicity and Estrogen Activities. Water Air \& Soil Pollution, DOI, 10.1007/s11270-020-04574-2, 2020.

25. ZHANG S., LI Y. Pathalate acid esters corrected with the summation of relative difference method in the construction of multispectral activity pharmacophore models and its application in molecular modifications. Spectroscopy Letters, 53 (5), 337, 2020.

26. QIU Y., ZHANG S., LI Y. High Ultraviolet Sensitivity of Phthalic Acid Esters with Environmental Friendliness after Modification through Pharmacophore Modeling Associated with the Solvation Effect. Polish Journal of Environmental Studies, 29 (3), 2303, 2020.

27. ZHANG H., ZHAO C., NA H. A Modified 3D-QSAR Model Based on Ideal Point Method and Its Application in the Molecular Modification of Plasticizers with Flame Retardancy and Eco-Friendliness. Polymers, DOI, 10.3390/ polym12091942, 2020.

28. ZHANG H., ZHAO C., NA H. Theoretical Design of Biodegradable Phthalic Acid Ester Derivatives in Marine and Freshwater Environments. Chemistry Open, 9 (10), 1033, 2020.

29. ZHANG H., ZHAO C., NA H. Enhanced Biodegradation of Phthalic Acid Ester' Derivatives by Plasticizer-Degrading Bacteria (Burkholderia cepacia, Archaeoglobus fulgidus, Pseudomonas aeruginosa) Using a Correction 3D-QSAR Model. Environmental Research and Public Health, DOI, 10.3390/ijerph17155299, 2020.

30. WEI L.L. Study on distribution and Migration of persistent organic pollutants in karst underground river systemtake Jila underground river and Longzhai underground river for example[D]. Chongqing Municipality, Southwest University, 2011 [In Chinese].

31. TONG L., GUO L., LV X., LI Y. Modification of polychlorinated phenols and evaluation of their toxicity, biodegradation and bioconcentration using threedimensional quantitative structure-activity relationship models. Journal of Molecular Graphics \& Modelling, 71, $1,2016$.

32. JACKSON S.H., COWAN-ELLSBERRY C.E., THOMAS G. Use of quantitative structural analysis to predict fish bioconcentration factors for pesticides. Journal of Agricultural and Food Chemistry, 57 (3), 958, 2009.

33. BANYIOVA K., CERNA M., MIKES O., KOMPRDOVA K., SHARMA A., GYALPO T., CUPR P., SCHERINGER M. Long-term time trends in human intake of POPs in the Czech Republic indicate a need for continuous monitoring. Environment International, 108, 1, 2017.

34. HUO X.X. Studying on the electronic structure and transmission characteristics of small fullerenes[D]. Jiangnan University, 2011 [In Chinese].

35. WENWEN GU., QING LI., YU LI. Environment-friendly PCN Derivatives Design and Environmental Behavior Simulation Based on Multi-activity 3D-QSAR Model and Molecular Dynamics Aided by L16 (26) Taguchi Experimental Design. Journal of Hazardous Material, DIO, 10.1016/j.jhazmat.2020.122339s, 2020.

36. GOLBRAIKH A., TROPSHA A. Beware of $\mathrm{q}^{2}$ !. Mol Graph Modell, 20, 269, 2002.

37. ZHENHUA CHU., YU LI. Designing Modified Polybrominated Diphenyl Ether BDE-47, BDE-99, BDE100, BDE-183, and BDE-209 Molecules with Decreased Estrogenic Activities using 3D-QSAR, Pharmacophore Models Coupled with Resolution V of the 210-3 Fractional Factorial Design and Molecular Docking. Journal of Hazardous Materials, 364, 151, 2019.

38. YUANYUAN ZHAO., YU LI Design of environmentally friendly neonicotinoid insecticides with bioconcentration tuning and Bi-directional selective toxic effects. Journal of Cleaner Production, 221, 113, 2019.

39. LI X., YE L., SHI W., LIU H., LIU C., QIAN X. In silico study on hydroxylated polychlorinated biphenyls as androgen receptor antagonists. Ecotoxicology and Environmental Safety, 92 (3), 258, 2013.

40. SALAHINEJAD M., GHASEMI J.B. 3D-QSAR studies on the toxicity of substituted benzenes to Tetrahymena 
pyriformis, CoMFA, CoMSIA and VolSurf approaches. Ecotoxicology and Environmental Safety, 105 (1), 128, 2014.

41. DAVIES R.P., DOBBS A.J. The prediction of bioconcentration in fish. Water Res, 18, 1253, 1984.

42. LV H.L., WANG B.G., YANG J.C. A group contributionbased model to predict organic solvent diffusivities in amorphous rubbery polymers. Polymers Journal, 39, 1167, 2007.
43. YANG T., YU T.L. Migration and extraction of plasticizers from PVC. Plastic additive, 5, 13, 2009 [In Chinese].

44. ZHAO Y.J., SI J.L. A method for rapidly calculating the volume and surface area of molecules based on elements and chemical bonds. Computer and Applied Chemistry, 30 (7), 739, 2013 [In Chinese].

45. HU C., WANG Z.Z., XU W.B., XU H.Y. QSPR studies on vapor pressure of poly and perfluorinated chemicals. Chemical Research and Application, 25 (1), 43, 2013. 